\title{
Synthesis and Characterization of Polypyrrole-Antimony (III) Oxide Hybrid Polymer Nanocomposites
}

\author{
Dr. N Dhachanamoorthi ${ }^{1}$ \\ ${ }^{1}$ Assistant Professor \& Head, \\ PG Department of Physics, Vellalar College for Women, \\ Erode, Tamilnadu, India.
}

\author{
Dr. M. Jothi ${ }^{2}$ \\ ${ }^{2}$ Assistant Professor, \\ PG Department of Physics, Vellalar College for Women, \\ Erode, Tamilnadu, India.
}

\author{
S. Tamilselvan ${ }^{3}$ \\ ${ }^{3}$ Assistant Professor of Physics, \\ Nandha Arts and Science College, \\ Erode, Tamilnadu, India
}

\begin{abstract}
The $\mathrm{PPy}_{-} \mathrm{Sb}_{2} \mathrm{O}_{3}$ nanocomposites with $\mathrm{Sb}_{2} \mathrm{O}_{3}$ $(<250 \mathrm{~nm})$ nanoparticles various weight percents were prepared by mechanical mixing. Fourier transform infrared (FTIR) spectroscopy, ultraviolet-visible (UV-Vis) spectroscopy, X-ray diffraction (XRD), thermogravimetric analysis (TGA), differential scanning calorimetry (DSC), scanning electron microscopy (SEM), and energy dispersive $\mathrm{X}$-ray analysis spectroscopy (EDAX) were used to characterize the $\mathrm{PPy}_{-} \mathrm{Sb}_{2} \mathrm{O}_{3}$ nanocomposites. The FTIR results indicated that there are some interactions between $\mathrm{PPy}$ and $\mathrm{Sb}_{2} \mathrm{O}_{3}$ nanoparticles. Such an interaction is likely caused by the formation of the coordinate bonding between the lone pair electron of atom in PPy chain with orbit of $\mathrm{Sb}$ atom of $\mathrm{Sb}_{2} \mathrm{O}_{3}$, indicating a reduction in the strength of $\mathrm{PPy}-\mathrm{Sb}_{2} \mathrm{O}_{3}$ interactions as the wt \% increases, which may lead to the broader size distribution of $\mathrm{Sb}_{2} \mathrm{O}_{3}$ nanoparticles dispersed in nanocomposites.
\end{abstract}

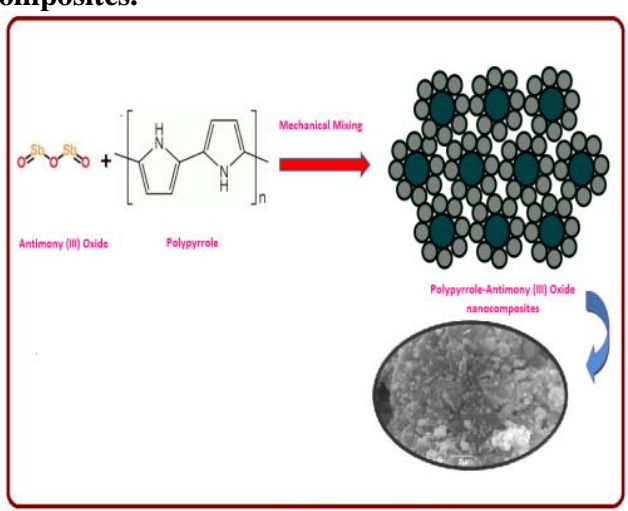

Schematic diagram $\mathrm{PPy}-\mathrm{Sb}_{2} \mathrm{O}_{3}$ nanocomposites

The UV-vis results of $\mathrm{PPy}-\mathrm{Sb}_{2} \mathrm{O}_{3}$ nanocomposites interactions is significantly increased by increasing the $\mathrm{Sb}_{2} \mathrm{O}_{3} \mathrm{wt} \%$, leading to reduce the energy level interval of benzenoid ring and hence result in a red shift. The XRD result indicates that PPy has been successfully anchored on the surface of $\mathrm{Sb}_{2} \mathrm{O}_{3} \mathrm{nPs}$ through the mechanical mixing method. The morphology and elemental composition analysis were characterized by using SEM and EDAX. This result indicates high interaction between PPy and metal oxides.

\section{INTRODUCTION}

Hybrid inorganic-organic nanocomposite materials have attracted more and more attention due to creating new materials which combine different functions and characteristics of individual materials. Different inorganic materials including carbon nanotubes, metal, metal oxides and nanosheets have been investigated in polymer matrices [1]. Nanocomposite materials have attracted a lot of interest due to their probable commercial exploitation as sensors, batteries, toners in copying machines, quantum electronic devices, smart windows and materials for electromagnetic shielding, etc. Nanocomposite materials made from nanoparticles of oxides and conducting polymers are the most interesting and challenging areas of research in recent times [2]. The conducting polymers, such as polythiophene, polypyrrole (PPy) and polyaniline have been exhaustively studied due to their outstanding mechanical and electrical properties, which afford applications in actuators, sensors and electrochromic devices [3]. Among the conducting polymers, PPy has attracted considerable attention because it is easy synthesis, it has relatively good quality environmental stability and its surface charge characteristics are can be customized by changing the dopant species into the material during the synthesis $[4,5]$. In the present work, we report the fabrication of conductive $\mathrm{PPy}-\mathrm{Sb}_{2} \mathrm{O}_{3}$ nanocomposites using mechanical mixing method. The chemical structures of the $\mathrm{PPy}-\mathrm{Sb}_{2} \mathrm{O}_{3}$ nanocomposites are characterized by Fourier transform infrared (FT-IR) spectroscopy and optical parameters are by using UV-vis characterization. The thermal stability of the $\mathrm{PPy}-\mathrm{Sb}_{2} \mathrm{O}_{3}$ nanocomposites is performed by thermogravime tric analysis (TGA) and differential scanning calorimetric (DSC). Scanning electron microscope (SEM) is used to characterize the dispersion of $\mathrm{Sb}_{2} \mathrm{O}_{3} \mathrm{nPs}$ and the morphology of the PPy- $\mathrm{Sb}_{2} \mathrm{O}_{3}$ nanocomposites. The effects of the $\mathrm{Sb}_{2} \mathrm{O}_{3}$ nPs on the crystallization structures of the PPy are also studied. In this present work, the inorganic-organic hybrid nanocomposite containing polypyrrole as the organic part and antimony (III) oxide as the inorganic part have been used for studying structural, optical and thermal properties. Such types of nanocomposite have shown to posses small grain size and high stability. To the best of our knowledge, this is the first 
ever attempt made to synthesis and investe of these nanocomposites with special properties.

\section{EXPERIMENTAL}

\subsection{Materials}

All of the chemical reagents used in this experiment were A.R. grade. The monomer pyrrole (PPy) and Dodecylbenzene Sulfonic acid (DBSNa) as dopant was purchased from Aldrich Chemical and purified by distillation under reduced pressure, stored in refrigerator before use. Antimony (III) oxide nanopowder, $<250 \mathrm{~nm}$ nanoparticle (98\% purity) from Aldrich Chemical, Ammonium peroxydisulfate (99\%, Merck), Ethonal (99\% purity, Merck), Acetone (99\% purity, Merck) were purchased from Merck chemical. The water used throughout the work is distilled water.

\subsection{The preparation of polypyrrole (PPy)}

The polypyrrole was synthesized by chemical oxidation polymerization under static condition in a lower temperature. About $900 \mathrm{ml}$ of de ionized water was taken in a flask and an arrangement for mechanical stirring. Dodecylbenzene sulfonic acid solution (DBSNa) as a dopant was dissolved in above $900 \mathrm{ml}$ of deionized water and the solution was well stirred in the flask. Monomer pyrrole was added in the above suspension solution and keeps stirring for 30 min. After 30 min ammonium peroxydisulfate $\left(\mathrm{NH}_{4}\right)_{2} \mathrm{~S}_{2} \mathrm{O}_{8}$ as an oxidant was added drop wise slowly to the good degree of polymerization is achieved the suspension solution was dark black in color. The entire solution mixture was continuously stirred well at $0-5^{\circ} \mathrm{C}$ and the reaction was continued for another $24 \mathrm{~h}$ over all time speed of rotation maintained at 700rpm. The product was filtered and washed with deionized water, ethanol and acetone, then dried under vacuum at $80^{\circ} \mathrm{C}$ for $24 \mathrm{~h}$. Experimental setup as shown in Fig.1.

\subsection{Synthesis of polypyrrole- $\mathrm{Sb}_{2} \mathrm{O}_{3}$ nanocomposites}

$\mathrm{PPy}-\mathrm{Sb}_{2} \mathrm{O}_{3}$ nanocomposites were synthesized using different wt\% of $\mathrm{Sb}_{2} \mathrm{O}_{3}$ with respect to polypyrrole which are referred as $\mathrm{PPy}-\mathrm{Sb}_{2} \mathrm{O}_{3}$ nanocomposites. Pure $\mathrm{PPy}$ was synthesized following the same procedure without $\mathrm{Sb}_{2} \mathrm{O}_{3}$ nanoparticles. The molar ratio of polymer (PPy) and metal Oxide $\mathrm{Sb}_{2} \mathrm{O}_{3}$ was 1:0.25 to prepare $\mathrm{PPy}-\mathrm{Sb}_{2} \mathrm{O}_{3}(25 \%)$ nanocomposites by using mechanical mixing method. Similarly the samples were prepared in the different weight $\%$ of $\mathrm{Sb}_{2} \mathrm{O}_{3}$ nanoparticles like $\mathrm{PPy}-\mathrm{Sb}_{2} \mathrm{O}_{3}(50 \%)$ and $\mathrm{PPy}-\mathrm{Sb}_{2} \mathrm{O}_{3}(100 \%)$ by the ratio $1: 0.50$ and $1: 1$ respectively.

\section{CHARACTERIZATION}

FT-IR spectra of the pure PPy, $\quad \mathrm{PPy}-\mathrm{Sb}_{2} \mathrm{O}_{3}$ nanocomposites, $\mathrm{Sb}_{2} \mathrm{O}_{3} \mathrm{nPs}$ samples were recorded at room temperature using FT-IR Spectrometer Make: Perkin Elmer; Model: Spectrum RX 1; Range: $400 \mathrm{~cm}^{-1}-4000 \mathrm{~cm}^{-1}$; Resolution: 4. The sample was prepared in the pellet form by mixing the polymer powder with $\mathrm{KBr}$ by the ratio $1: 10$ and pressing it in the Perkin Elmer hydraulic device using 15 ton pressure.

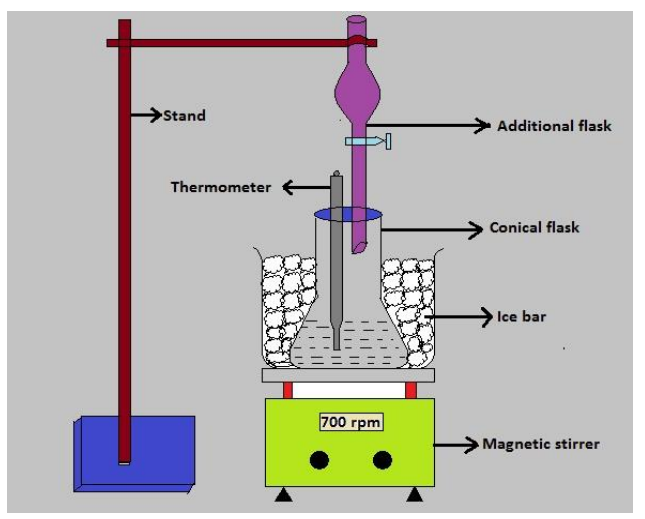

Fig.1 Experimental setup for chemical oxidative polymerization method

UV-vis spectra of the synthesized $\mathrm{PPy}-\mathrm{Sb}_{2} \mathrm{O}_{3}$ nanocomposites powder were determined using a UV-vis spectrometer, Model: Lambda 35; Range: $400 \mathrm{~nm}-1100 \mathrm{~nm}$; Resolution: 4; Mode of operation: 1.Transmittance (T \%) and Absorbance (A \%) 2. Reflectance (R \%). X-ray diffraction patterns of $\mathrm{PPy}-\mathrm{Sb}_{2} \mathrm{O}_{3}$ nanocomposites samples performed using advance diffractometer with monochromatic $\mathrm{CuK \alpha}$ radiation $(\lambda=1.54 \AA)$ are used to identify crystalline nature of the samples. The crystallite size was determined from Scherrer relation.

$$
D=\frac{K \lambda}{\beta \cos \theta}
$$

where, $\mathrm{D}$ is the crystallite size, $\mathrm{K}$ is the shape factor for the average crystallite (w0.9), $\lambda$ is the wavelength of the X-ray which is $1.54 \AA$ for $\mathrm{Cu}$ target, $\mathrm{B}$ is the full width at half maxima of the crystalline peak in radians, $\theta$ is the angle between incident and reflected rays. Thermogravimetric properties of the pure PPy and $\mathrm{PPy}-\mathrm{Sb}_{2} \mathrm{O}_{3}$ nanocomposites were studied in instrument used: STA449 F3 Jupiter; Temperature range: $\mathrm{RT}$ to $500{ }^{\circ} \mathrm{C}$; Heating rate: $10 \mathrm{~K} / \mathrm{min}$; Atmosphere: Nitrogen; Sample Carrier: TG-DSC Sample Carrier; Sample Crucible: TG-DSC Alumina Crucible with lid. The microstructure, size and morphology of the synthesized polypyrrole as well as their dispersity in the PPy$\mathrm{Sb}_{2} \mathrm{O}_{3}$ nanocomposites could be determined with the help of scanning electron microscopy (SEM) images were obtained on Make: JEOL; Modal: JSM 6390; Made in Japan. Energy dispersive $\mathrm{X}$ - ray spectroscopy employed to analyze the chemical compositions of nanocomposites was carried out using Make: Oxford Instruments; Modal: INCA Pental FET 3; Made in England.

\section{RESULT AND DISCUSSION}

\subsection{FTIR spectral analysis}

The FTIR spectra of pure PPy, $\mathrm{PPy}-\mathrm{Sb}_{2} \mathrm{O}_{3}(25-100 \%)$ nanocomposites and pure $\mathrm{Sb}_{2} \mathrm{O}_{3} \mathrm{nPs}$ are shown in Fig.2. The main transmittance peaks of PPy are appeared at $3402.05 \mathrm{~cm}^{-1}$ and $1547.23 \mathrm{~cm}^{-1}$ could be corresponded to the $\mathrm{N}-\mathrm{H}$ stretching vibration and symmetric stretching vibration of $\mathrm{C}-\mathrm{C}$ bond in the PPy ring, respectively. The band at $1397.53 \mathrm{~cm}^{-1}$ is assigned to $\mathrm{N}-\mathrm{H}$ bending vibration bond. The transmittance 
peaks appeared at $1184.22 \mathrm{~cm}^{-1}$ and $905.96 \mathrm{~cm}^{-1}$ was attributed to the in-plane bending vibration of $\mathrm{C}-\mathrm{H}$ bond and the $\mathrm{C}-\mathrm{H}$ out-of-plane bending vibration indicating the polymerization of pyrrole respectively [6]. The FTIR spectrum of the $\mathrm{PPy}-\mathrm{Sb}_{2} \mathrm{O}_{3}$ (25\%) nanocomposite demonstrated the peaks at $3396.57 \mathrm{~cm}^{-1}, 1545.98 \mathrm{~cm}^{-1}, 1381.84 \mathrm{~cm}^{-1}, 1185.86$ $\mathrm{cm}^{-1}$, and $908.86 \mathrm{~cm}^{-1}$ that are considered to arise from pyrrole ring stretching, N-H stretching vibration, C-C symmetric stretching vibration, $\mathrm{N}-\mathrm{H}$ bending vibration, $\mathrm{C}-\mathrm{H}$ in plane bending vibration and $\mathrm{C}-\mathrm{H}$ out-of-plane bending respectively. The transmittance peaks and corresponding stretching vibration of pure $\mathrm{PPy}, \mathrm{PPy}-\mathrm{Sb}_{2} \mathrm{O}_{3}$ nanocomposites was shown in Table.1. These results confirmed the presence of PPy moieties in the nanocomposites. Interestingly, all peak positions shifted towards higher values after $\mathrm{Sb}$ ions adsorption. The delocalized $\pi$ electrons in PPy matrix, which are involved in the skeletal vibration of PPy ring, are affected by the doping ions in the polymer matrix. Different types of dopants in the PPy backbone may disturb the conjugate structure of PPy and this limit the extent of charge delocalization along the polymer chains, leading to red shift. However, as for $\mathrm{PPy}-\mathrm{Sb}_{2} \mathrm{O}_{3}$ nanocomposites, except the peaks of PPy, the broad band between 500 and $950 \mathrm{~cm}^{-1}$ are attributed to the $\mathrm{Sb}-\mathrm{O}$ bond, suggesting that the $\mathrm{Sb}_{2} \mathrm{O}_{3}$ was embedded in PPy matrix. The results indicated that there are some interactions between PPy and $\mathrm{Sb}_{2} \mathrm{O}_{3}$ particles. Such an interaction is likely caused by the formation of the coordinate bonding between the lone pair electron of atom in PPy chain with orbit of $\mathrm{Sb}$ atom of $\mathrm{Sb}_{2} \mathrm{O}_{3}$, indicating the strength of PPy$\mathrm{Sb}_{2} \mathrm{O}_{3}$ interactions, as the wt \% increases, which may lead to the broader size distribution of $\mathrm{Sb}_{2} \mathrm{O}_{3}$ particles dispersed in nanocomposites. Compared to pure $\mathrm{PPy}$, the characteristic peaks of $\mathrm{PPy}-\mathrm{Sb}_{2} \mathrm{O}_{3}$ nanocomposites slightly shifted to higher wavelength, indicating the strong interaction at the interface. Besides, the characteristic peaks of $\mathrm{PPy}-\mathrm{Sb}_{2} \mathrm{O}_{3}$ are well maintained in the nanocomposites, indicating that PPy has been successfully compounded with $\mathrm{Sb}_{2} \mathrm{O}_{3}$ without changing chemical composition. Comparing to the corresponding peaks of pure PPy, the peaks of $\mathrm{PPy}-\mathrm{Sb}_{2} \mathrm{O}_{3}$ shifted towards lower wavenumber. This shifting of absorption bands may be due to the action of hydrogen bonding between the hydroxyl groups on the surface of $\mathrm{Sb}_{2} \mathrm{O}_{3}$ nPs and the amine groups in the PPy molecular chains. Similar observations of absorption shifting peaks of $\mathrm{PPy}-\mathrm{Sb}_{2} \mathrm{O}_{3}$ towards are obtained in lower wavenumber. This result indicates that the $\mathrm{PPy}-\mathrm{Sb}_{2} \mathrm{O}_{3}$ nanocomposites have been successful synthesized and the observed shift indicates the interaction between PPy and nPs.

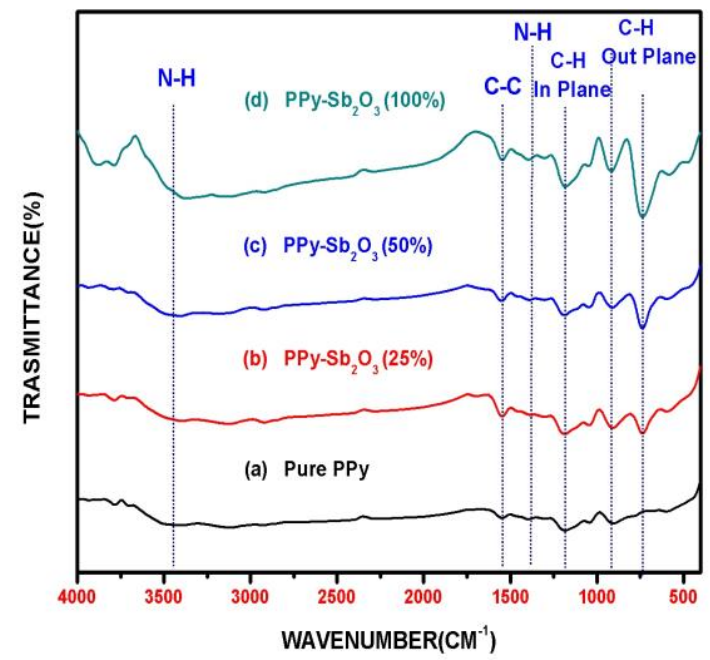

Fig.2 FTIR spectra of pure PPy (a) and $\mathrm{PPy}-\mathrm{Sb}_{2} \mathrm{O}_{3}$ nanocomposites (b, c \& d)

\begin{tabular}{|c|c|c|c|c|c|}
\hline $\begin{array}{l}\text { Sample } \\
\text { Name }\end{array}$ & $\begin{array}{c}\mathrm{N}-\mathrm{H} \\
\text { stretching } \\
\text { vibrations } \\
\left(\mathrm{cm}^{-1}\right)\end{array}$ & $\begin{array}{c}\text { C-C ring } \\
\text { symmetric } \\
\text { stretching } \\
\text { vibrations } \\
\quad\left(\mathrm{cm}^{-1}\right) \\
\end{array}$ & $\begin{array}{c}\mathrm{N}-\mathrm{H} \\
\text { bending } \\
\text { vibrations } \\
\left(\mathrm{cm}^{-1}\right)\end{array}$ & $\begin{array}{c}\text { In-plane } \\
\text { C-H } \\
\text { bending } \\
\text { Vibrations } \\
\left(\mathrm{cm}^{-1}\right) \\
\end{array}$ & $\begin{array}{c}\text { Out-plane } \\
\text { C-H } \\
\text { bending } \\
\text { Vibrations } \\
\left(\mathrm{cm}^{-1}\right)\end{array}$ \\
\hline $\begin{array}{l}\text { Pure } \\
\text { PPy }\end{array}$ & 3402.05 & 1547.23 & 1397.53 & 1184.22 & 905.96 \\
\hline $\begin{array}{c}\text { PPy- } \\
\mathrm{Sb}_{2} \mathrm{O}_{3} \\
(25 \%)\end{array}$ & 3396.57 & 1545.98 & 1381.84 & 1185.86 & 908.86 \\
\hline $\begin{array}{c}\text { PPy- } \\
\mathrm{Sb}_{2} \mathrm{O}_{3} \\
(50 \%)\end{array}$ & 3410.94 & 1548.74 & 1387.97 & 1187.47 & 911.61 \\
\hline $\begin{array}{c}\text { PPy- } \\
\mathrm{Sb}_{2} \mathrm{O}_{3} \\
(100 \%)\end{array}$ & 3373.71 & 1544.73 & 1395.43 & 1181.12 & 916.23 \\
\hline
\end{tabular}

Table.1 FTIR data of pure PPy and $\mathrm{PPy}-\mathrm{Sb}_{2} \mathrm{O}_{3}$ nanocomposites

\section{2. $U V$-vis absorption spectral analysis}

The UV-vis spectra of pure PPy (a), $\mathrm{PPy}-\mathrm{Sb}_{2} \mathrm{O}_{3}$ (b,c, d) nanocomposites and pure $\mathrm{Sb}_{2} \mathrm{O}_{3}$ (e) are shown in Fig.3. The absorption reveals that there is different composition and morphology in ranging $\mathrm{Sb}_{2} \mathrm{O}_{3}$ concentration from $25-100 \%$ in $\mathrm{PPy}-\mathrm{Sb}_{2} \mathrm{O}_{3}$ nanocomposites. However, as the characteristic absorption bands of pure PPy are obtained in the wavelengths range of 250-300 nm, 450-450 nm and 900-1000 nm. UV-vis analysis was also conducted to analyze the PPy are presented in Fig.4 (a), in which the intermediates exhibit an absorption band appeared at about $473 \mathrm{~nm}$. This band is due to the formation of phenazine-like structures in this stage. These bands are assigned to the formation of PPy. The first absorption band corresponds to the $\pi-\pi^{*}$ electron transition within benzenoid segments. The second and the third bands correspond to the doped state and the polaron formation in PPy respectively. From the spectroscopic and theoretical data indicate, that the absorption band at $400-500 \mathrm{~nm}(4-3 \mathrm{eV})$ is assigned to $\pi-\pi^{*}$ transition of PPy. The band gap of each case is determined from Tauc plot which is shown in Table.2. 


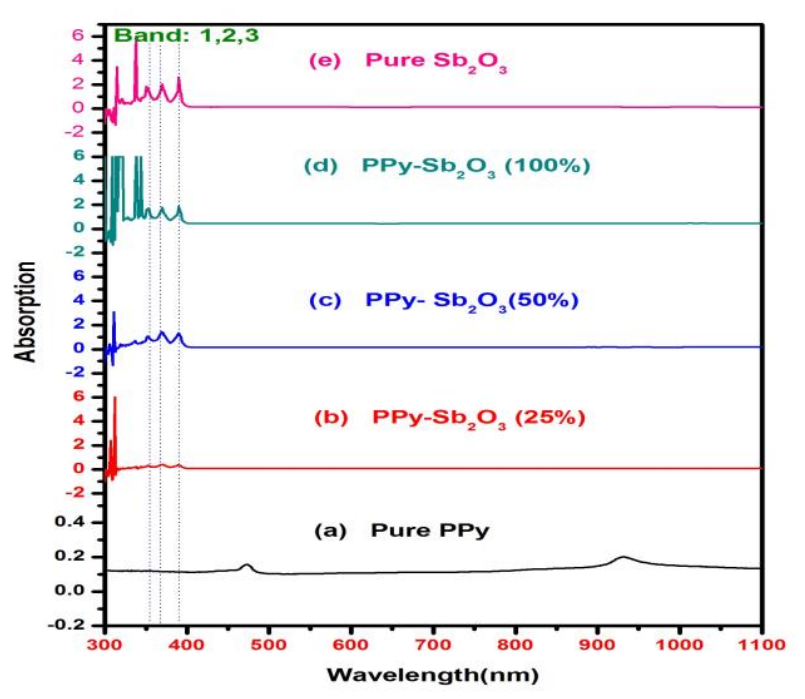

Fig.3 UV-vis spectra of pure PPy (a), $\mathrm{PPy}_{-} \mathrm{Sb}_{2} \mathrm{O}_{3}$ nanocomposites (b, c, d) and pure $\mathrm{Sb}_{2} \mathrm{O}_{3} \mathrm{nPs}$

\begin{tabular}{|c|c|c|c|c|c|c|c|}
\hline \multirow[b]{2}{*}{$\begin{array}{l}\text { Sample } \\
\text { Name }\end{array}$} & \multicolumn{3}{|c|}{ Wavelength (nm) } & \multicolumn{3}{|c|}{ Absorption } & \multirow{2}{*}{$\begin{array}{l}\text { Band } \\
\text { gap } \\
(\mathrm{eV})\end{array}$} \\
\hline & $\begin{array}{c}\text { Band: } \\
1\end{array}$ & $\begin{array}{c}\text { Band: } \\
2\end{array}$ & $\begin{array}{c}\text { Band: } \\
\mathbf{3}\end{array}$ & $\begin{array}{c}\text { Band: } \\
1\end{array}$ & $\begin{array}{l}\text { Band: } \\
\quad 2\end{array}$ & $\begin{array}{c}\text { Band: } \\
\mathbf{3}\end{array}$ & \\
\hline $\begin{array}{l}\text { Pure } \\
\text { PPy }\end{array}$ & 260 & 473 & 931 & 0.1826 & 0.1581 & 0.2017 & 3.46 \\
\hline $\begin{array}{l}\text { PPy- } \\
\mathrm{Sb}_{2} \mathrm{O}_{3} \\
(25 \%)\end{array}$ & 343 & 360 & 379 & 0.3393 & 0.4155 & 0.3951 & 3.04 \\
\hline $\begin{array}{l}\text { PPy- } \\
\mathrm{Sb}_{2} \mathrm{O}_{3} \\
(50 \%)\end{array}$ & 342 & 359 & 379 & 1.0751 & 1.4434 & 1.3211 & 1.76 \\
\hline $\begin{array}{c}\text { PPy- } \\
\mathrm{Sb}_{2} \mathrm{O}_{3} \\
(\mathbf{1 0 0 \%})\end{array}$ & 343 & 359 & 380 & 1.7405 & 1.7130 & 1.8569 & 1.49 \\
\hline $\begin{array}{c}\text { Pure } \\
\mathrm{Sb}_{2} \mathrm{O}_{3}\end{array}$ & 340 & 359 & 380 & 1.8181 & 2.0666 & 2.5913 & 1.71 \\
\hline
\end{tabular}

Table. 3 Crystallographic parameters of pure PPy,

$\mathrm{PPy}-\mathrm{Sb}_{2} \mathrm{O}_{3}$ nanocomposites and pure $\mathrm{Sb}_{2} \mathrm{O}_{3} \mathrm{nPs}$

Among the various cases, the highest band gap energy was obtained for pure PPy and then the band gap was decreased with increasing $\mathrm{Sb}_{2} \mathrm{O}_{3}$ concentration which is clearly shown in the Table.2. The PPy- $\mathrm{Sb}_{2} \mathrm{O}_{3}$ interactions is significantly increased by increasing the $\mathrm{Sb}_{2} \mathrm{O}_{3} \mathrm{wt} \%$, leading to reduce the energy level interval of benzenoid ring and hence, result in a red shift. The FTIR spectra of the nanocomposites shown in Fig.3 also support this conclusion. Upon doping PPy exhibits unusual electronic structure due to electron-phonon coupling. Polarons and bipolarons states appear within the band gap, which gives rise to the broad band at wave length 900-1000 $\mathrm{nm}$ in the case of pure PPy. Generally, the optical band gap in a semiconductor is determined by plotting absorption coefficients $(\alpha)$ as $(\alpha h v)^{1 / m}$ vs. hv where ' $m$ ' represents the nature of the transition and $h v$ is the photon energy. Now ' $\mathrm{m}$ ' may have different values, such as $\frac{1}{2}, 2, \frac{3}{2}$ and 3 for allowed direct, allowed indirect, forbidden direct and forbidden indirect transitions respectively.

$$
\alpha=\frac{A\left(h v-E_{g}\right)^{\frac{1}{2}}}{h v}
$$

where ' $\mathrm{A}$ ' is the absorption constant for a direct transition. For allowed direct transition one can plot $(\alpha h v)^{2}$ vs. hv as shown in Fig. 4 and extrapolate the linear portion of it to $\alpha=0$ value to obtain the corresponding band gap.

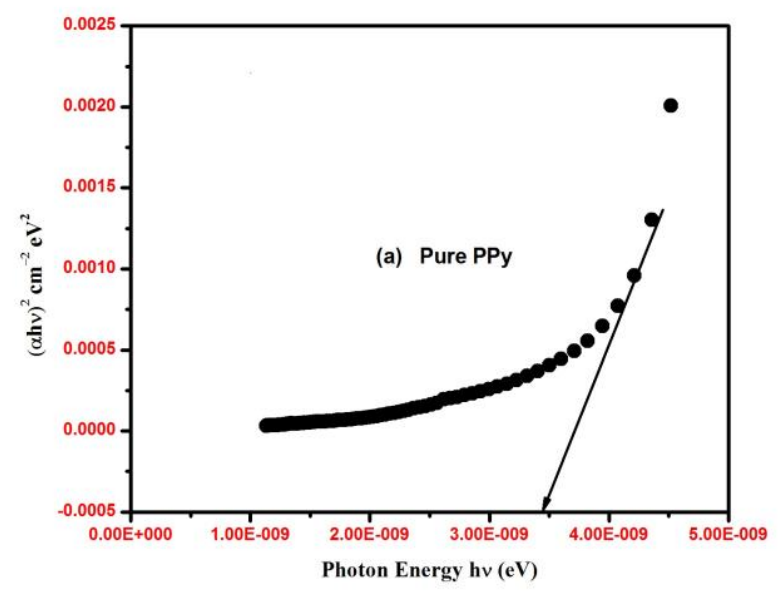

Fig.4a

The optical absorption coefficient ( $\alpha$ ) near the absorption edge for direct interband transitions is given by the equation (1). The band gap of PPy with antimony concentration implies that electronic structure of PPy is affected [8,9]. UV-Vis spectral data and the band gap of pure $\mathrm{PPy}, \mathrm{PPy}-\mathrm{Sb}_{2} \mathrm{O}_{3}(25-100 \%)$ nanocomposites and pure $\mathrm{Sb}_{2} \mathrm{O}_{3}$ are as shown in Table.2.

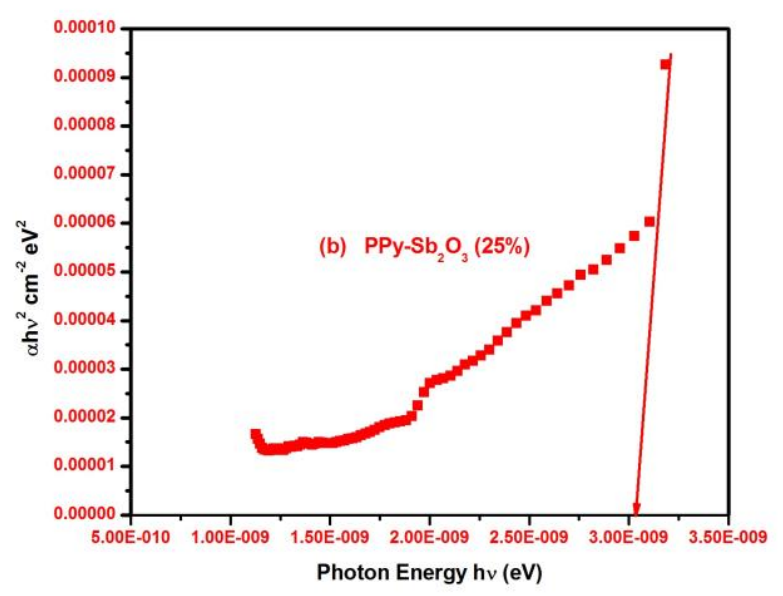

Fig.4b 


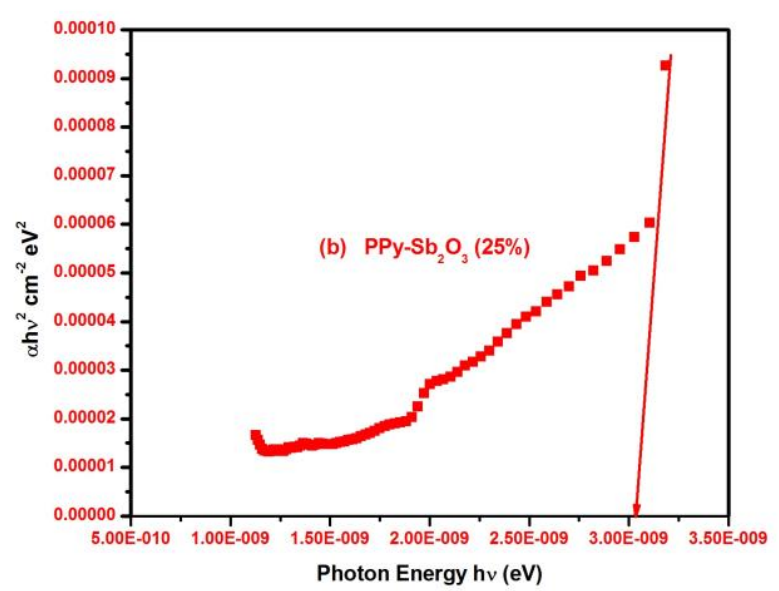

Fig. $4 \mathrm{c}$

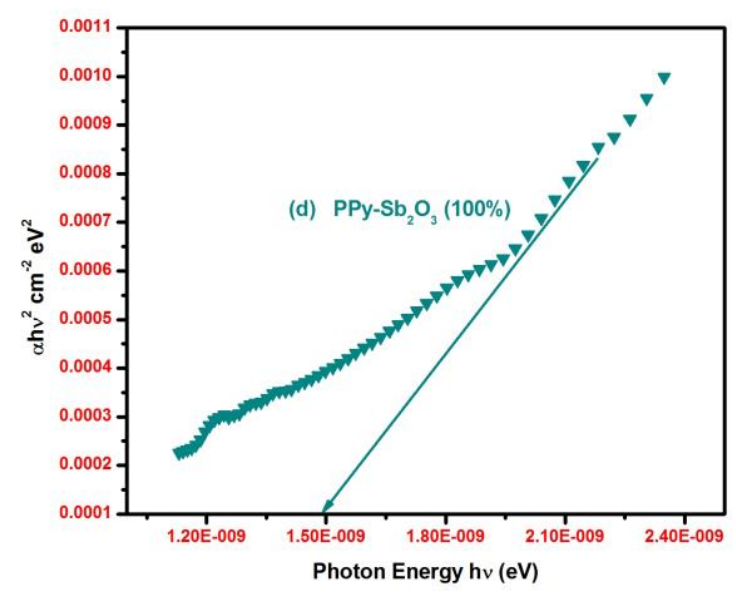

Fig.4d

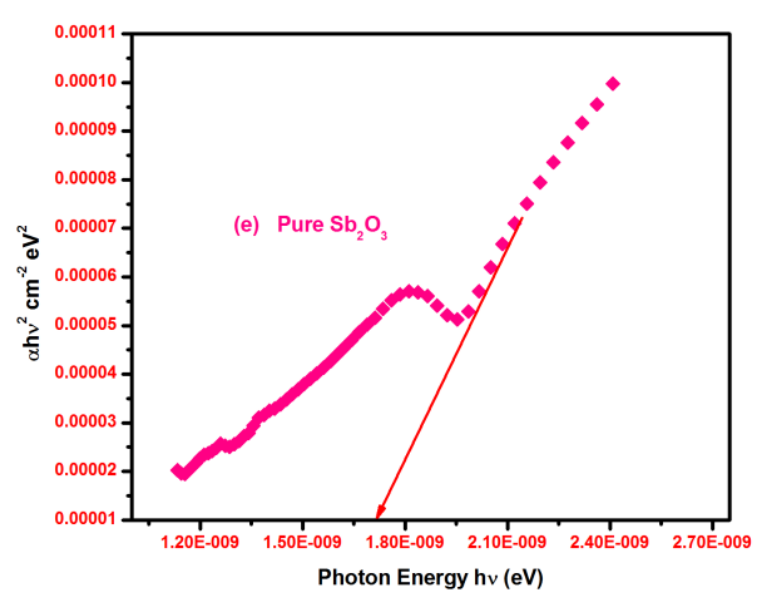

Fig.4d

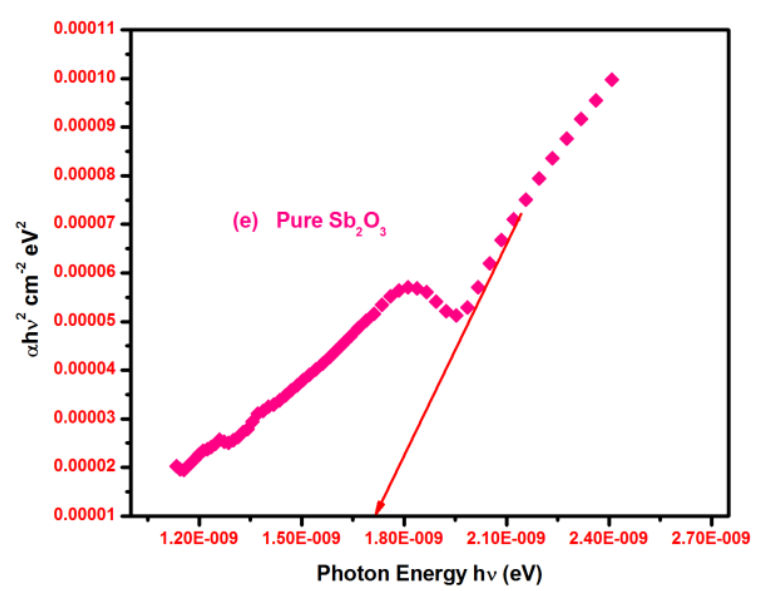

Fig. $4 \mathrm{e}$

Fig.4a-4e Tauc plot for $(\alpha h v)^{2}$ vs hv of pure $\mathrm{PPy}, \mathrm{PPy}_{-} \mathrm{Sb}_{2} \mathrm{O}_{3}$ nanocomposites and pure $\mathrm{Sb}_{2} \mathrm{O}_{3} \mathrm{nPs}$

\subsection{X-Ray diffraction studies}

Fig.5 shows the XRD patterns of pure PPy, PPy$\mathrm{Sb}_{2} \mathrm{O}_{3}$ nanocomposites (25-100\%) and pure $\mathrm{Sb}_{2} \mathrm{O}_{3}$ nPs which is a evidence of crystalline nature of the samples. The XRD pattern of pure PPy shows a broad peak and sharp peak appeared at $23.04^{\circ}$ and $44.36^{\circ}$ respectively, which indicates the crystalline nature. XRD curve of PPy shows that the PPy prepared in the absence of $\mathrm{Sb}_{2} \mathrm{O}_{3} \mathrm{nPs}$ is amorphous in nature. The crystallite sizes of the PPy were estimated from X-ray line broadening using Scherer's formula. It can be seen clearly from the XRD patterns of $\mathrm{Sb}_{2} \mathrm{O}_{3} \mathrm{nPs}$, that the $\mathrm{Sb}_{2} \mathrm{O}_{3} \mathrm{nPs}$ showed a single-phase in nature. There was no secondary phase detected and the high intensity of the peaks revealed the crystalline nature of the as $\mathrm{Sb}_{2} \mathrm{O}_{3}$ nPs. Obviously, the diffraction peaks of the $\mathrm{Sb}_{2} \mathrm{O}_{3}$ nPs appear in the $\mathrm{PPy}-\mathrm{Sb}_{2} \mathrm{O}_{3}$ nanocomposites from the Fig.5 (b,c,d) the intensity of these peaks becomes stronger with increasing the nanoparticle loadings, while the two original peaks of PPy show a reduced intensity at $2 \theta=23.04$ and $44.36^{\circ}$. The XRD pattern also confirm the presence of antimony in the $\mathrm{PPy}-\mathrm{Sb}_{2} \mathrm{O}_{3}$ (25-100\%) nanocomposites and pure $\mathrm{Sb}_{2} \mathrm{O}_{3}$ the crystallize size as-calculated, where the average crystallize size are $97 \mathrm{~nm}$ (25\%), $170 \mathrm{~nm} \mathrm{(50 \% ),} 176 \mathrm{~nm} \mathrm{(100 \% )} \mathrm{and} 152 \mathrm{~nm}$ (pure $\mathrm{Sb}_{2} \mathrm{O}_{3}$ ). The strain and dislocation density of pure PPy, PPy-Sb ${ }_{2} \mathrm{O}_{3}$ nanocomposites (25-100\%), pure $\mathrm{Sb}_{2} \mathrm{O}_{3}$ nPs data are seen in Table.3. The parameters are slightly changed with the addition of $\mathrm{Sb}_{2} \mathrm{O}_{3}$ nPs. Furthermore, these results revealed the amorphous nature of PPy in the nanocomposites, suggesting that the addition of $\mathrm{Sb}_{2} \mathrm{O}_{3}$ nPs retain the crystallization of the PPy molecular chains. This may be because when PPy is adsorbed on the surface of the $\mathrm{Sb}_{2} \mathrm{O}_{3}$ nPs. The increasing trend intensity indicating that the $\mathrm{Sb}_{2} \mathrm{O}_{3}$ greatly increased due to the adsorption of PPy molecular chains on the surface of the $\mathrm{Sb}_{2} \mathrm{O}_{3}$ nPs. In order to study the effect of the addition of $\mathrm{Sb}_{2} \mathrm{O}_{3}$ nPs in PPy matrix, a careful analysis of the position of the XRD peak indicates that, there is a shifting in peak's position towards lowering $2 \theta$ value, but in this case, the crystallinity of $\mathrm{Sb}_{2} \mathrm{O}_{3} \mathrm{nPs}$ was found to be disturbed in the $\mathrm{PPy}-\mathrm{Sb}_{2} \mathrm{O}_{3}$ nanocomposites. However, in the present work the crystallinity of $\mathrm{Sb}_{2} \mathrm{O}_{3}$ is not disturbed by PPy 
molecular chain on the surface of $\mathrm{Sb}_{2} \mathrm{O}_{3} \mathrm{nPs}$ as can be seen from Fig.6. The shifting of the peak's position clearly indicates that $\mathrm{PPy}-\mathrm{Sb}_{2} \mathrm{O}_{3}$ nanoparticles are incorporating into the PPy polymer matrix. The broad weak diffraction peak of PPy still exists, but its intensity decreases. This indicates a strong effect of the $\mathrm{Sb}_{2} \mathrm{O}_{3} \mathrm{nPs}$ on the structures of crystalline of the formed PPy and the interaction between PPy backbone and $\mathrm{Sb}_{2} \mathrm{O}_{3} \mathrm{nPs}$.

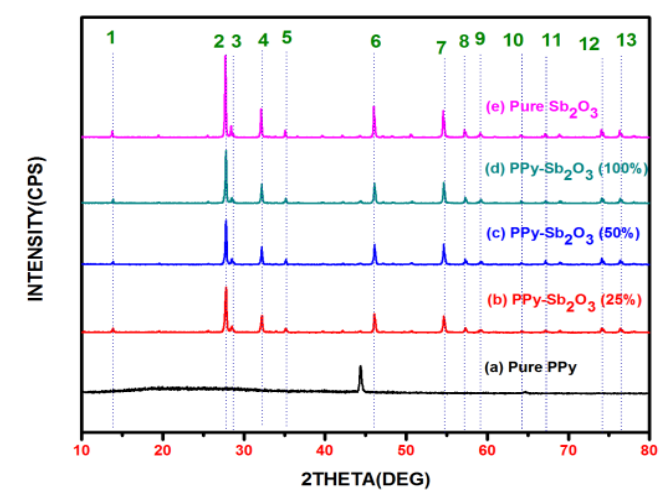

Fig.5 X-Ray diffraction patterns of pure PPy (a), $\mathrm{PPy}-\mathrm{Sb}_{2} \mathrm{O}_{3}$ nanocomposites $(b, c, d)$ and pure $\mathrm{Sb}_{2} \mathrm{O}_{3}$ nPs (e)
This result indicates that, PPy has been successfully anchored on the surface of $\mathrm{Sb}_{2} \mathrm{O}_{3}$ NPs through the mechanical mixing method. However, the characteristic peak intensities of $\mathrm{PPy}-\mathrm{Sb}_{2} \mathrm{O}_{3}$ nanocomposite gradually decreased with increasing the weight percentage of $\mathrm{Sb}_{2} \mathrm{O}_{3}$, indicating the incorporation of $\mathrm{Sb}_{2} \mathrm{O}_{3}$ into the polymer matrix. Previous literature also support that the parent work that the introduction of $\mathrm{Sb}_{2} \mathrm{O}_{3}$ will affect the crystalline behavior of PPy [10-12].

\begin{tabular}{|c|c|c|c|c|c|c|c|}
\hline & \multicolumn{7}{|c|}{ Pure PPy } \\
\hline & $2 \theta$ & FWHM & Intensity & $\begin{array}{l}\text { d Spacing } \\
\text { Value }\end{array}$ & $\begin{array}{c}\text { Crystallize size } \\
(\mathbf{n m})\end{array}$ & Strain & Dislocation density \\
\hline $\mathbf{1}$ & 23.04 & 0.071 & 263 & 3.8570 & 114 & 0.0006 & $1.30 * 10^{-14}$ \\
\hline 2 & 44.36 & 0.094 & 980 & 2.0404 & 91 & 0.0004 & $8.32 * 10^{-15}$ \\
\hline \multirow[b]{2}{*}{ Peak No } & \multicolumn{7}{|c|}{$\mathrm{PPy}_{-\mathrm{Sb}_{2} \mathrm{O}_{3}(25 \%)}$} \\
\hline & $2 \theta$ & FWHM & Intensity & $\begin{array}{l}\text { d Spacing } \\
\text { Value }\end{array}$ & $\begin{array}{c}\text { Crystallize size } \\
\text { (nm) }\end{array}$ & Strain & Dislocation density \\
\hline 1 & 13.88 & 0.118 & 130 & 6.3749 & 67 & 0.0018 & $0.20 * 10^{-15}$ \\
\hline 2 & 27.80 & 0.118 & 1647 & 3.2065 & 69 & 0.0009 & $4.80 * 10^{-15}$ \\
\hline 3 & 28.52 & 0.118 & 220 & 3.1271 & 69 & 0.0009 & $4.80 * 10^{-15}$ \\
\hline 4 & 32.22 & 0.165 & 610 & 2.7760 & 50 & 0.0001 & $2.50 * 10^{-15}$ \\
\hline 5 & 35.20 & 0.071 & 140 & 2.5475 & 117 & 0.0004 & $1.37 * 10^{-14}$ \\
\hline 6 & 46.10 & 0.118 & 570 & 1.9673 & 73 & 0.0005 & $5.34 * 10^{-15}$ \\
\hline 7 & 54.64 & 0.071 & 617 & 1.6783 & 125 & 0.0002 & $1.58 * 10^{-14}$ \\
\hline 8 & 57.26 & 0.118 & 170 & 1.6076 & 76 & 0.0004 & $5.87 * 10^{-15}$ \\
\hline 9 & 59.14 & 0.071 & 103 & 1.5609 & 128 & 0.0002 & $1.65 * 10^{-14}$ \\
\hline 10 & 64.14 & 0.118 & 57 & 1.4507 & 79 & 0.0003 & $6.30 * 10^{-15}$ \\
\hline 11 & 68.96 & 0.071 & 77 & 1.3606 & 135 & 0.0002 & $1.84 * 10^{-14}$ \\
\hline 12 & 74.08 & 0.071 & 163 & 1.2787 & 140 & 0.0001 & $1.96 * 10^{-14}$ \\
\hline \multirow[t]{2}{*}{13} & 76.44 & 0.071 & 170 & 1.2450 & 142 & 0.0001 & $2.02 * 10^{-14}$ \\
\hline & \multicolumn{7}{|c|}{$\mathrm{PPy}_{-} \mathrm{Sb}_{2} \mathrm{O}_{3}(50 \%)$} \\
\hline Peak No & $2 \theta$ & FWHM & Intensity & $\begin{array}{l}\text { d Spacing } \\
\text { Value }\end{array}$ & $\begin{array}{c}\text { Crystallize size } \\
\text { (nm) }\end{array}$ & Strain & Dislocation density \\
\hline 1 & 14.00 & 0.047 & 213 & 6.3205 & 170 & 0.0007 & $2.89 * 10^{-14}$ \\
\hline 2 & 27.94 & 0.047 & 1747 & 3.1907 & 174 & 0.0003 & $3.03 * 10^{-14}$ \\
\hline 3 & 28.76 & 0.047 & 113 & 3.1016 & 174 & 0.0003 & $3.04 * 10^{-14}$ \\
\hline 4 & 32.34 & 0.071 & 567 & 2.7659 & 116 & 0.0004 & $1.35 * 10^{-14}$ \\
\hline 5 & 35.28 & 0.071 & 153 & 2.5419 & 117 & 0.0004 & $1.37 * 10^{-14}$ \\
\hline 6 & 46.24 & 0.071 & 607 & 1.9617 & 121 & 0.0003 & $1.47 * 10^{-14}$ \\
\hline 7 & 54.80 & 0.047 & 533 & 1.6738 & 190 & 0.0001 & $3.62 * 10^{-14}$ \\
\hline 8 & 57.42 & 0.047 & 173 & 1.6035 & 192 & 0.0001 & $3.71 * 10^{-14}$ \\
\hline 9 & 59.32 & 0.071 & 110 & 1.5566 & 128 & 0.0002 & $1.65 * 10^{-14}$ \\
\hline 10 & 64.28 & 0.047 & 83 & 1.4479 & 199 & 0.0001 & $3.98 * 10^{-14}$ \\
\hline 11 & 69.04 & 0.047 & 80 & 1.3593 & 205 & 0.0001 & $4.20 * 10^{-14}$ \\
\hline 12 & 74.20 & 0.047 & 153 & 1.2770 & 211 & 0.0001 & $4.48 * 10^{-14}$ \\
\hline \multirow[t]{2}{*}{13} & 76.60 & 0.047 & 103 & 1.2428 & 215 & 0.0001 & $4.63 * 10^{-14}$ \\
\hline & \multicolumn{7}{|c|}{$\mathrm{PPy}_{-\mathrm{Sb}_{2} \mathrm{O}_{3}(100 \%)}$} \\
\hline Peak No & $2 \theta$ & FWHM & Intensity & $\begin{array}{l}\text { d Spacing } \\
\text { Value }\end{array}$ & $\begin{array}{c}\text { Crystallize size } \\
\text { (nm) }\end{array}$ & Strain & Dislocation density \\
\hline 1 & 13.88 & 0.047 & 153 & 6.3749 & 170 & 0.0007 & $2.89 * 10^{-14}$ \\
\hline 2 & 27.80 & 0.047 & 1907 & 3.2065 & 174 & 0.0003 & $3.02 * 10^{-14}$ \\
\hline
\end{tabular}




\begin{tabular}{|c|c|c|c|c|c|c|c|}
\hline 3 & 28.48 & 0.047 & 210 & 3.1314 & 174 & 0.0003 & $3.03 * 10^{-14}$ \\
\hline 4 & 32.20 & 0.047 & 713 & 2.7776 & 175 & 0.0003 & $3.09 * 10^{-14}$ \\
\hline 5 & 35.26 & 0.047 & 107 & 2.5433 & 177 & 0.0002 & $3.14 * 10^{-14}$ \\
\hline 6 & 46.10 & 0.047 & 733 & 1.9673 & 183 & 0.0002 & $3.37 * 10^{-14}$ \\
\hline 7 & 54.30 & 0.047 & 47 & 1.6880 & 189 & 0.0001 & $3.60 * 10^{-14}$ \\
\hline 8 & 57.28 & 0.094 & 220 & 1.6071 & 96 & 0.0003 & $9.26 * 10^{-15}$ \\
\hline 9 & 59.20 & 0.047 & 140 & 1.5595 & 194 & 0.0001 & $3.77 * 10^{-14}$ \\
\hline 10 & 64.38 & 0.047 & 53 & 1.4459 & 199 & 0.0001 & $3.98 * 10^{-14}$ \\
\hline 11 & 68.90 & 0.047 & 87 & 1.3617 & 203 & 0.0001 & $4.19 * 10^{-14}$ \\
\hline 12 & 74.10 & 0.071 & 183 & 1.2784 & 140 & 0.0001 & $1.96 * 10^{-14}$ \\
\hline 13 & 76.32 & 0.047 & 123 & 1.2467 & 214 & 0.0001 & $4.61 * 10^{-14}$ \\
\hline \multirow[b]{2}{*}{ Peak No } & \multicolumn{7}{|c|}{ Pure $\mathrm{Sb}_{2} \mathrm{O}_{3}$} \\
\hline & $2 \theta$ & FWHM & Intensity & $\begin{array}{l}\text { d Spacing } \\
\text { Value }\end{array}$ & $\begin{array}{c}\text { Crystallize size } \\
\text { (nm) }\end{array}$ & Strain & Dislocation density \\
\hline 1 & 13.80 & 0.047 & 253 & 6.4117 & 170 & 0.0007 & $2.89 * 10^{-14}$ \\
\hline 2 & 27.72 & 0.118 & 2957 & 3.2155 & 69 & 0.0009 & $4.80 * 10^{-15}$ \\
\hline 3 & 28.42 & 0.071 & 430 & 3.1379 & 115 & 0.0005 & $1.33 * 10^{-14}$ \\
\hline 4 & 32.10 & 0.094 & 1037 & 2.7861 & 87 & 0.0006 & $7.72 * 10^{-15}$ \\
\hline 5 & 35.06 & 0.047 & 273 & 2.5573 & 177 & 0.0002 & $3.13^{*} 10^{-14}$ \\
\hline 6 & 46.02 & 0.094 & 1130 & 1.9760 & 91 & 0.0004 & $8.42 * 10^{-15}$ \\
\hline 7 & 54.56 & 0.047 & 980 & 1.6806 & 190 & 0.0001 & $3.61 * 10^{-14}$ \\
\hline 8 & 58.84 & 0.047 & 67 & 1.5681 & 193 & 0.0001 & $3.76 * 10^{-14}$ \\
\hline 9 & 59.14 & 0.071 & 180 & 1.5609 & 128 & 0.0002 & $1.65^{*} 10^{-14}$ \\
\hline 10 & 64.10 & 0.071 & 90 & 1.4516 & 131 & 0.0002 & $1.74 * 10^{-14}$ \\
\hline 11 & 67.22 & 0.047 & 70 & 1.3916 & 202 & 0.0001 & $4.11 * 10^{-14}$ \\
\hline 12 & 74.04 & 0.047 & 263 & 1.2793 & 211 & 0.0001 & $4.47 * 10^{-14}$ \\
\hline 13 & 76.24 & 0.047 & 103 & 1.2478 & 214 & 0.0001 & $4.61 * 10^{-14}$ \\
\hline
\end{tabular}

Table.3 Crystallographic parameters of pure PPy, $\mathrm{PPy}-\mathrm{Sb}_{2} \mathrm{O}_{3}$ nanocomposites and pure $\mathrm{Sb}_{2} \mathrm{O}_{3} \mathrm{nPs}$

\subsection{Thermogravimetric analysis}

The thermogravimetric analysis of pure PPy, PPy$\mathrm{Sb}_{2} \mathrm{O}_{3}$ (25-100\%) nanocomposites and pure $\mathrm{Sb}_{2} \mathrm{O}_{3} \mathrm{nPs}$ is shown in Fig.6. To investigate the weight loss of the assynthesized pure $\mathrm{PPy}, \mathrm{PPy}-\mathrm{Sb}_{2} \mathrm{O}_{3}(25-100 \%)$ nanocomposites and pure $\mathrm{Sb}_{2} \mathrm{O}_{3} \mathrm{nPs}$ samples, the thermogravimetric analysis has been carried out in a nitrogen atmosphere. In order to see the effect of temperature on the thermal behavior of the polymer thermogravimetric analysis of $\mathrm{PPy}^{-\mathrm{Sb}_{2} \mathrm{O}_{3}}$ nanocomposites has been carried out from 25-500 ${ }^{\circ} \mathrm{C}$ temperature. To investigate the thermal properties and the interaction between PPy and $\mathrm{Sb}_{2} \mathrm{O}_{3}$, TGA analysis has been carried out through decomposition curve. From the Fig.6 (a) pure PPy undergoes two-step decompositions are observed. The first one is appeared at $110{ }^{\circ} \mathrm{C}$ which is due to the removal of adsorbed water resulting with a weight loss of $53.99 \%$. The second step of decomposition starts from $200{ }^{\circ} \mathrm{C}$ and goes up to $450{ }^{\circ} \mathrm{C}$ with about $26.31 \%$ weight loss. Finally the residual mass and residual temperature of pure PPy is 19.70 and 497.8 ${ }^{\circ} \mathrm{C}$. Degradation of $\mathrm{PPy}-\mathrm{Sb}_{2} \mathrm{O}_{3}(25 \%)$ nanocomposite takes place in five steps. The first three steps of weight loss observed at $200{ }^{\circ} \mathrm{C}$ is due to the removal of adsorbed water and the remaining second step (between $200{ }^{\circ} \mathrm{C}$ and $450{ }^{\circ} \mathrm{C}$ ) of weight loss is due to the breakdown of the polymer backbone in the nanocomposites as shown in Fig. 7 (b).

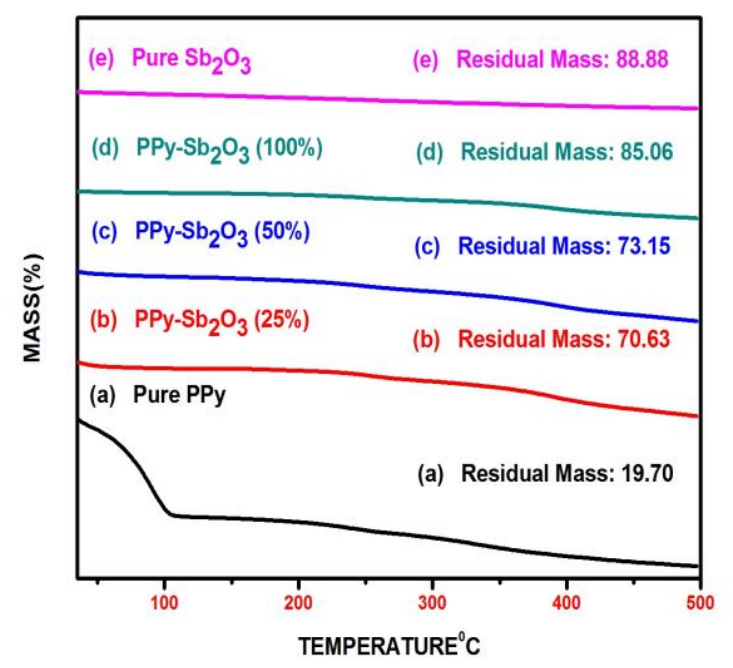

Fig.6 TGA spectra of pure PPy (a), $\mathrm{PPy}-\mathrm{Sb}_{2} \mathrm{O}_{3}$ nanocomposites (b,c,d) and pure $\mathrm{Sb}_{2} \mathrm{O}_{3}$ nPs (e)

\begin{tabular}{|c|c|c|c|}
\hline \multicolumn{4}{|c|}{ Pure PPy } \\
\hline $\begin{array}{c}\text { Mass } \\
\text { Change }\end{array}$ & Mass & $\begin{array}{c}\text { Residual } \\
\text { Mass }\end{array}$ & $\begin{array}{c}\text { Residual } \\
\text { Temp }\end{array}$ \\
\hline Stage: 1 & -53.99 & \multirow{5}{*}{19.70} & \multirow{5}{*}{497.80} \\
\hline Stage: 2 & -26.31 & & \\
\hline Stage: 3 & - & & \\
\hline Stage: 4 & - & & \\
\hline Stage: 5 & - & & \\
\hline \multicolumn{4}{|c|}{$\mathrm{PPy}_{-} \mathrm{Sb}_{2} \mathrm{O}_{3}(25 \%)$} \\
\hline $\begin{array}{c}\text { Mass } \\
\text { Change }\end{array}$ & Mass & $\begin{array}{c}\text { Residual } \\
\text { Mass }\end{array}$ & $\begin{array}{c}\text { Residual } \\
\text { Temp }\end{array}$ \\
\hline
\end{tabular}




\begin{tabular}{|c|c|c|c|}
\hline Stage: 1 & -3.07 & \multirow{5}{*}{70.63} & \multirow{5}{*}{497.70} \\
\hline Stage: 2 & -2.02 & & \\
\hline Stage: 3 & -4.03 & & \\
\hline Stage: 4 & -4.31 & & \\
\hline Stage: 5 & -15.94 & & \\
\hline \multicolumn{4}{|c|}{$\mathrm{PPy}_{-\mathrm{Sb}_{2} \mathrm{O}_{3}(50 \%)}$} \\
\hline $\begin{array}{c}\text { Mass } \\
\text { Change }\end{array}$ & Mass & $\begin{array}{l}\text { Residual } \\
\text { Mass }\end{array}$ & $\begin{array}{l}\text { Residual } \\
\text { Temp }\end{array}$ \\
\hline Stage: 1 & -3.21 & \multirow{5}{*}{73.15} & \multirow{5}{*}{498.00} \\
\hline Stage: 2 & -1.97 & & \\
\hline Stage: 3 & -4.32 & & \\
\hline Stage: 4 & -3.73 & & \\
\hline Stage: 5 & -13.62 & & \\
\hline \multicolumn{4}{|c|}{$\mathrm{PPy}_{-\mathrm{Sb}_{2} \mathrm{O}_{3}(100 \%)}$} \\
\hline $\begin{array}{c}\text { Mass } \\
\text { Change }\end{array}$ & Mass & $\begin{array}{l}\text { Residual } \\
\text { Mass }\end{array}$ & $\begin{array}{c}\text { Residual } \\
\text { Temp }\end{array}$ \\
\hline Stage: 1 & -1.23 & \multirow{6}{*}{85.06} & \multirow{6}{*}{497.08} \\
\hline Stage: 2 & -0.43 & & \\
\hline Stage: 3 & -1.62 & & \\
\hline Stage: 4 & -1.59 & & \\
\hline Stage: 5 & -2.08 & & \\
\hline Stage: 6 & -7.99 & & \\
\hline \multicolumn{4}{|c|}{ Pure $\mathrm{Sb}_{2} \mathrm{O}_{3}$} \\
\hline $\begin{array}{c}\text { Mass } \\
\text { Change }\end{array}$ & Mass & $\begin{array}{l}\text { Residual } \\
\text { Mass }\end{array}$ & $\begin{array}{l}\text { Residual } \\
\text { Temp }\end{array}$ \\
\hline Stage: 1 & -3.41 & \multirow{6}{*}{88.88} & \multirow{6}{*}{497.90} \\
\hline Stage: 2 & -3.51 & & \\
\hline Stage: 3 & -4.20 & & \\
\hline Stage: 4 & - & & \\
\hline Stage: 5 & - & & \\
\hline Stage: 6 & - & & \\
\hline
\end{tabular}

Table.4 TGA parameters of pure $\mathrm{PPy}, \mathrm{PPy}_{-} \mathrm{Sb}_{2} \mathrm{O}_{3}$ nanocomposites and pure $\mathrm{Sb}_{2} \mathrm{O}_{3} \mathrm{nPs}$

The residual mass and residual temperature of $\mathrm{PPy}-\mathrm{Sb}_{2} \mathrm{O}_{3}$ (25\%) nanocomposite is 70.63 and $497.7{ }^{\circ} \mathrm{C}$ respectively. Mass changes, residual mass, residual temp of pure PPy, PPy$\mathrm{Sb}_{2} \mathrm{O}_{3}$ (25-100\%) nanocomposites and pure $\mathrm{Sb}_{2} \mathrm{O}_{3}$ nPs are shown in Table.4.The mass change of $\mathrm{PPy}-\mathrm{Sb}_{2} \mathrm{O}_{3}(25-100 \%)$ nanocomposites have five stages of weight loss are obtained for this nanocomposites while the spectrum pure $\mathrm{Sb}_{2} \mathrm{O}_{3} \mathrm{nPs}$ have two weight loss appeared in which the weight loss is decreased with increasing $\mathrm{Sb}$ ion concentration and the residual mass of $\mathrm{PPy}-\mathrm{Sb}_{2} \mathrm{O}_{3}(25-100 \%)$ nanocomposites are $70.63(25 \%), 73.15(50 \%), 85.06(100 \%)$. This data clearly reveals the residual mass are increased $\mathrm{Sb}$ ion content and with have constant residual temperature [13,14]. By comparing the thermo graphs of synthesized are pure PPy and nanocomposites, one can be understood, the different thermal behavior of the materials. The residual mass increased with the ionic concentration of $\mathrm{Sb}_{2} \mathrm{O}_{3}$ in $\mathrm{PPy}-\mathrm{Sb}_{2} \mathrm{O}_{3}$ nanocomposite materials. These results show that the $\mathrm{PPy}-\mathrm{Sb}_{2} \mathrm{O}_{3}$ nanocomposites materials have remarkable improvement in thermal stability. These results confirm the strong interaction between polypyrrole and $\mathrm{Sb}_{2} \mathrm{O}_{3}$ forming a stable nanocomposites.

\subsection{Differential scanning calorimetric analysis}

Differential scanning calorimetric spectrum of pure $\mathrm{PPy}, \mathrm{PPy}-\mathrm{Sb}_{2} \mathrm{O}_{3}$ (25-100\%) nanocomposites and pure $\mathrm{Sb}_{2} \mathrm{O}_{3}$ nPs were shown in Fig.8. Fig. 7 (a) shows the DSC of pure PPy have broad endothermic peak appeared at around 370.3 ${ }^{\circ} \mathrm{C}$, this peak reveals the removel of water molecules from the pure PPy molecules. DSC spectrum of pure PPy have sharp exothermic peaks appeared, exothermic peak was shown at about $95.4{ }^{\circ} \mathrm{C}$, which was the complex peak, area of this peak is $756.5 \mathrm{~J} / \mathrm{g}$; the onset and endset temperature of the complex peak is $65.2{ }^{\circ} \mathrm{C}, 110.3{ }^{\circ} \mathrm{C}$ respectively, this is presumably due to the polymer decomposition [15].

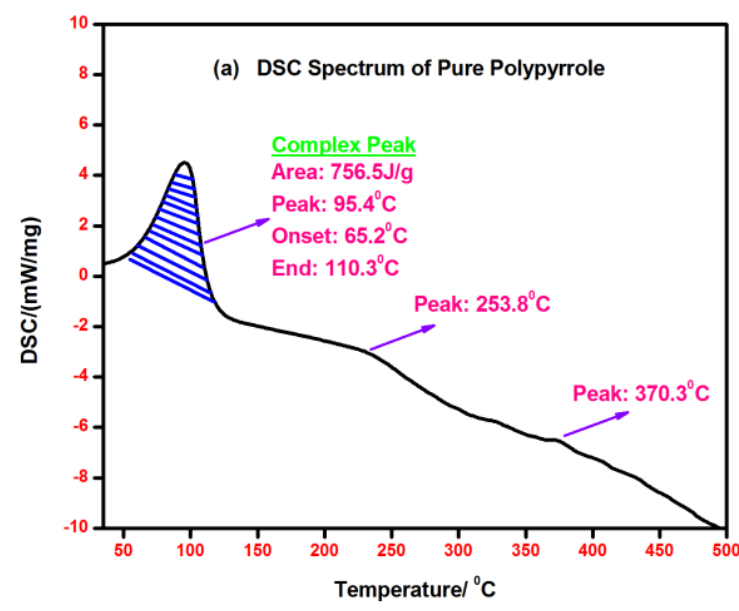

Fig.7a

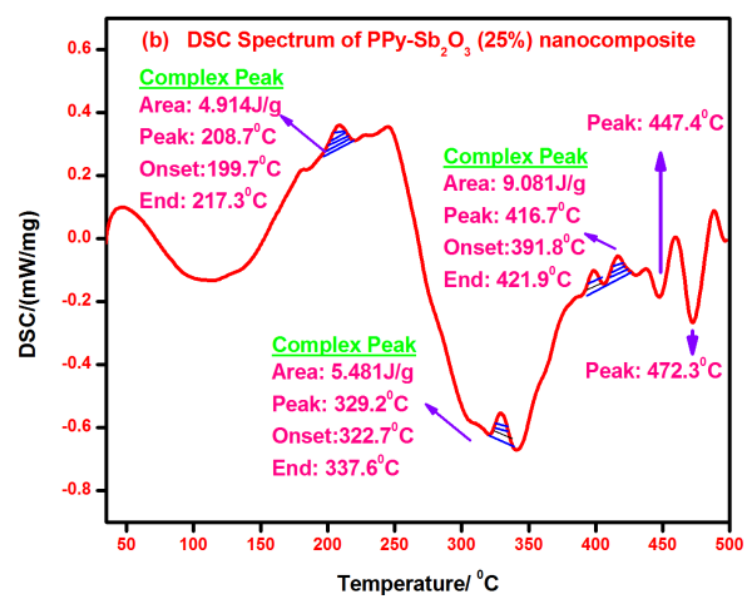

Fig.7b 


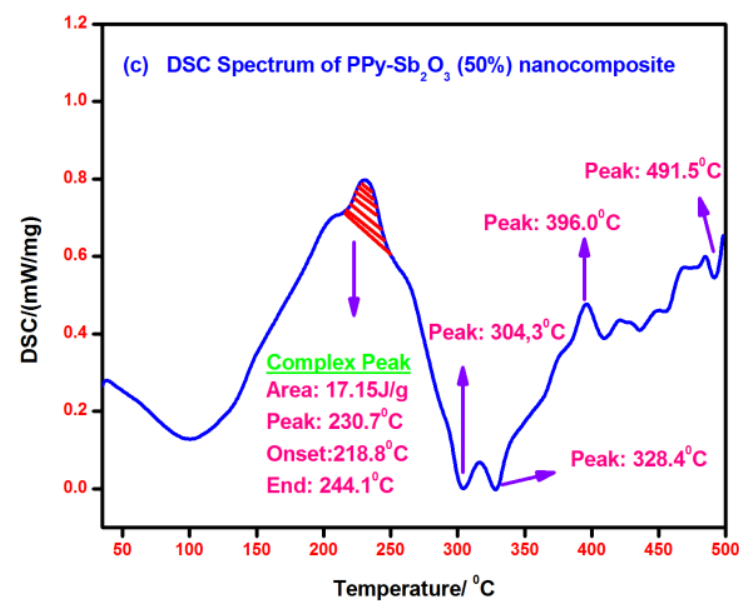

Fig.7c

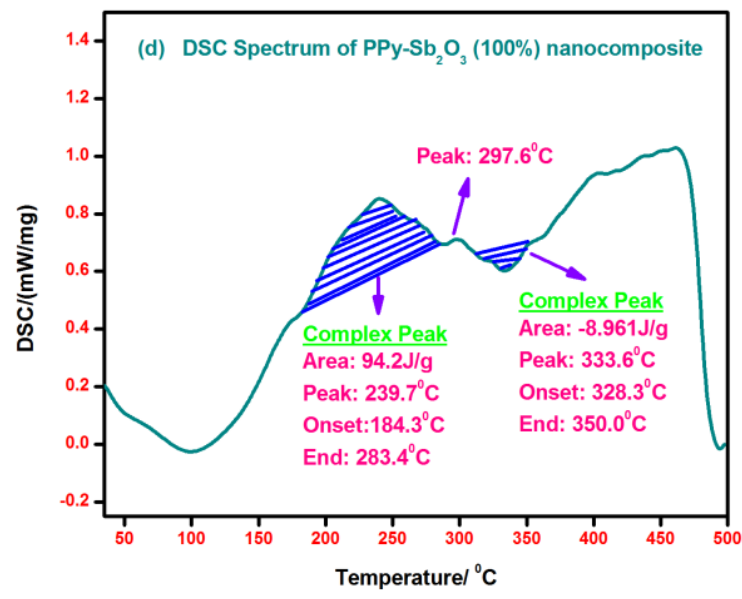

Fig.7d

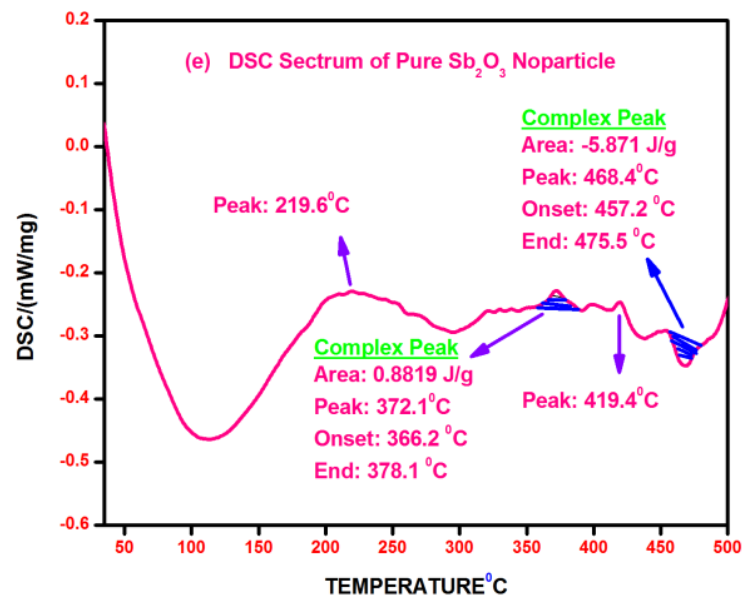

Fig.7e

Fig.7a-7e DSC spectra of pure $\mathrm{PPy}, \mathrm{PPy}_{-} \mathrm{Sb}_{2} \mathrm{O}_{3}$ nanocomposites and pure $\mathrm{Sb}_{2} \mathrm{O}_{3} \mathrm{nPs}$

The DSC spectrum of $\mathrm{PPy}^{-\mathrm{Sb}_{2} \mathrm{O}_{3}} \quad(25-100 \%)$ nanocomposites is shown in Fig.7 (b-d). The exothermic peaks appeared in the $\mathrm{PPy}-\mathrm{Sb}_{2} \mathrm{O}_{3}$ spectrum which named the complex peaks. From $\mathrm{PPy}-\mathrm{Sb}_{2} \mathrm{O}_{3}$ (25-100\%) nanocomposites spectrum which have complex peaks and the area of this complex peaks are $5.481 \mathrm{~J} / \mathrm{g}, 17.150 \mathrm{~J} / \mathrm{g}$, and $94.200 \mathrm{~J} / \mathrm{g}$. To compare these nanocomposites, the area of the complex peaks is increased with increasing the $\mathrm{Sb}_{2} \mathrm{O}_{3}$ concentration. The peaks indicating that, the polymer decomposition was found to be present in all ratios (25-100\%) of nanocomposites. The peaks indicating that the polymer decomposition was found to be present in $\mathrm{PPy}-\mathrm{Sb}_{2} \mathrm{O}_{3}$ (25-100\%), but that was clearly absent in pure $\mathrm{Sb}_{2} \mathrm{O}_{3} \mathrm{nPs}$ samples. Despite the degradation of $\mathrm{PPy}-\mathrm{Sb}_{2} \mathrm{O}_{3}(25-100 \%)$ nanocomposites samples indicating the gradual enhancement of thermal stability of the polymer chain with increasing the amount of $\mathrm{Sb}_{2} \mathrm{O}_{3}$. The exothermic peak disappeared for pure $\mathrm{Sb}_{2} \mathrm{O}_{3}$ sample, indicating strong interaction of the oxide with the polymer chain [16].

\subsection{Scanning electron microscopic studies}

Scanning electron microscopy (SEM) images of the pure $\mathrm{PPy}, \mathrm{PPy}-\mathrm{Sb}_{2} \mathrm{O}_{3}(25-100 \%)$ nanocomposites and pure $\mathrm{Sb}_{2} \mathrm{O}_{3} \mathrm{nPs}$ are shown in Fig. 8(a-e). The micrographs of pure PPy powder (Fig.8a) show big globular clusters of polymers. The surface morphology of pure PPy changed completely, when it was converted to the nanocomposites with $\mathrm{Sb}_{2} \mathrm{O}_{3}$ (Fig.8b-d), which established the interaction of $\mathrm{Sb}_{2} \mathrm{O}_{3}$ surface with the polymer chain. The white colour is $\mathrm{Sb}_{2} \mathrm{O}_{3} \mathrm{nPs}$ and light coloured shell is PPy in the nanocomposites. The prepared nanocomposite exists as relatively loose aggregates of $\mathrm{PPy}-\mathrm{Sb}_{2} \mathrm{O}_{3}$ with crystallize size of $100-250 \mathrm{~nm}$ which is observed from SEM study. The amorphous polypyrrole matrix can restrict the further growth of $\mathrm{Sb}_{2} \mathrm{O}_{3}$ nanocrystals and avoid their further aggregation in the chemical reaction process. According to above results, it can be summarized that, the parameter modulation of PPy in presence of $\mathrm{Sb}_{2} \mathrm{O}_{3} \mathrm{nPs}$ affects not only the final morphology but also the structure of $\mathrm{Sb}_{2} \mathrm{O}_{3}$ nPs within the $\mathrm{PPy}-\mathrm{Sb}_{2} \mathrm{O}_{3}$ nanocomposites.

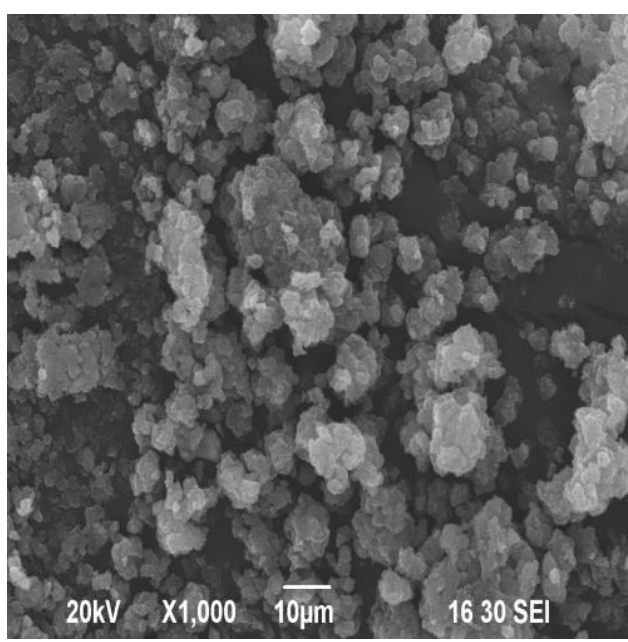

Fig.8a 


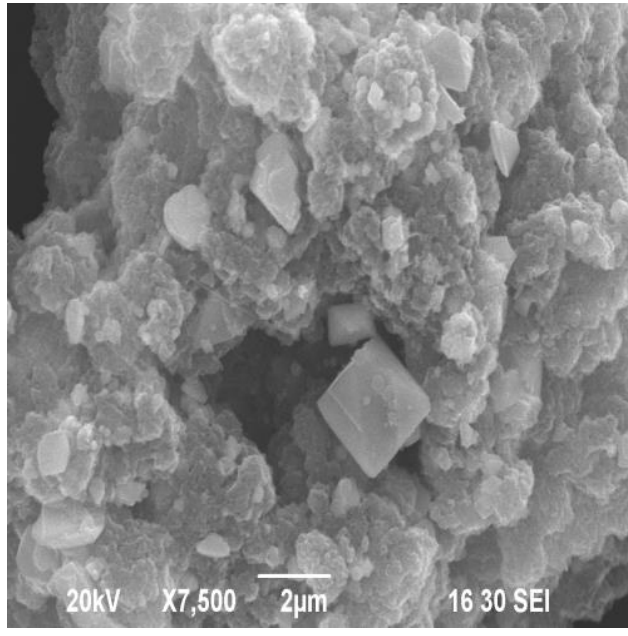

Fig.8b

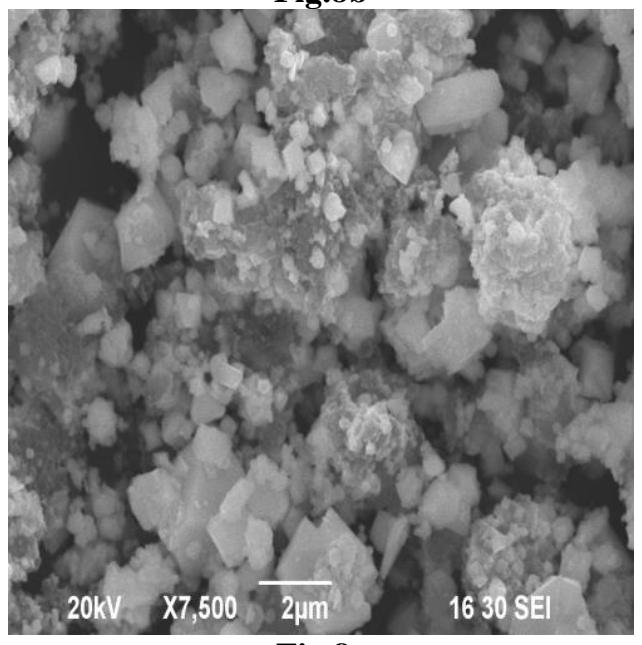

Fig.8c

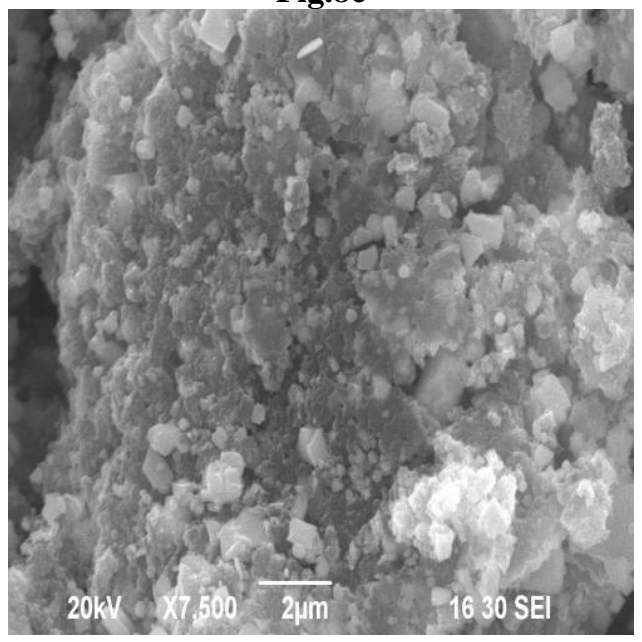

Fig.8d

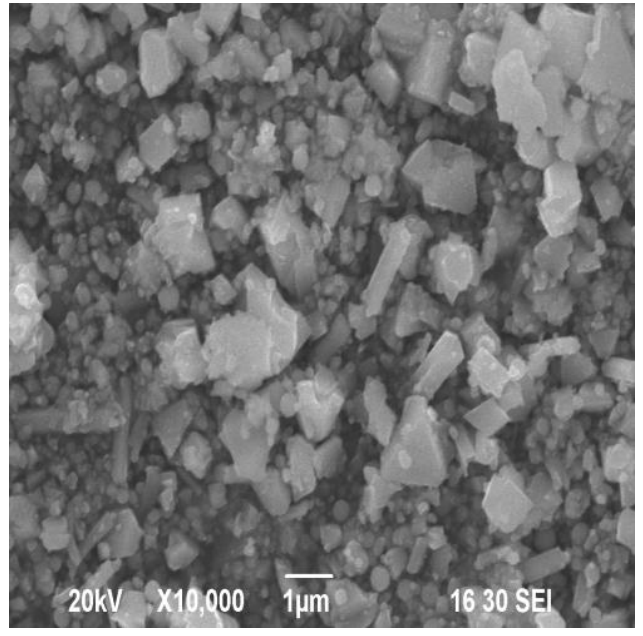

Fig.8e

Fig.8a-8e SEM images of pure PPy (a), $\mathrm{PPy}-\mathrm{Sb}_{2} \mathrm{O}_{3}$ nanocomposites (b,c,d), pure $\mathrm{Sb}_{2} \mathrm{O}_{3} \mathrm{nPs}(\mathrm{e})$

Succeeded in controlling $\mathrm{PPy}-\mathrm{Sb}_{2} \mathrm{O}_{3}$ morphology, the investigation was turned to explore, the formation mechanism of the $\mathrm{PPy}-\mathrm{Sb}_{2} \mathrm{O}_{3}$ morphology through characterizing the intermediates obtained in different reaction stages. The change in the surface morphology has been observed with increasing composition of $\mathrm{Sb}_{2} \mathrm{O}_{3} \quad\left(25-100\right.$ wt \%) in $\mathrm{PPy}-\mathrm{Sb}_{2} \mathrm{O}_{3}$ nanocomposites. The complex, stringy, interconnected network is a general feature of the morphology of $\mathrm{PPy}-\mathrm{Sb}_{2} \mathrm{O}_{3}$ nanocomposites. At higher (100 wt \%) of nanocomposites, the connected path way become more and more dense morphology are observed due to excess doping as the PPy$\mathrm{Sb}_{2} \mathrm{O}_{3}$ is approached. At this higher percentage of $\mathrm{PPy}-\mathrm{Sb}_{2} \mathrm{O}_{3}$ nanocomposites; the morphology appears almost foam like with $\mathrm{PPy}-\mathrm{Sb}_{2} \mathrm{O}_{3}$ network surrounded by $\mathrm{Sb}_{2} \mathrm{O}_{3}$. Thus $\mathrm{Sb}_{2} \mathrm{O}_{3}$ provides large conduction island thereby, reducing the conduction path through the nanocomposites [17].

\subsection{Energy dispersive $X$-ray analysis}

Fig. 9(a-e) shows the EDAX spectrum of the pure $\mathrm{PPy}, \mathrm{PPy}-\mathrm{Sb}_{2} \mathrm{O}_{3}(25-100 \%)$ nanocomposites and pure $\mathrm{Sb}_{2} \mathrm{O}_{3}$ nPs. The corresponding chemical composition is listed in Table.5. Fig.9a illustrates the element weight (\%) of C, O, and $\mathrm{S}$ of pure PPy sample was $69.32 \%, 24.24 \%$ and $6.44 \%$ respectively. It is seen that $\mathrm{C}, \mathrm{O}, \mathrm{S}$ and $\mathrm{Sb}$ elements are detected in the $\mathrm{PPy}-\mathrm{Sb}_{2} \mathrm{O}_{3}(25-100 \%)$ nanocomposites, which indicates that $\mathrm{O}$ and $\mathrm{Sb}$-ions have been doped into the PPy matrix successfully. The spectrum of pure $\mathrm{PPy}, \mathrm{PPy}-\mathrm{Sb}_{2} \mathrm{O}_{3}$ (25-100\%) nanocomposites and pure $\mathrm{Sb}_{2} \mathrm{O}_{3}$ nPs shows of the carbon molecules weight $\%$ are $69.32 \%, 40.66 \%, 30.02 \%$, $17.87 \%$ and $14.80 \%$ which is element composition in which decreasing trend is appeared for the same element composition changes were obtained for oxygen and sulfur molecules weights, and the weight $\%$ of antimony ion are $35.72 \%, 49.98$ $\%, 62.05 \%$ and $85.20 \%$, for this chemical composition increasing trend was appeared. As shown in Fig.9b an element like carbon, sulfur, oxygen and antimony of $\mathrm{PPy}-\mathrm{Sb}_{2} \mathrm{O}_{3}$ nanocomposite samples which compare due to pure PPy, the element contents of carbon, oxygen and sulfur was decreased, 
Antimony alone increased with increasing the concentration of $\mathrm{Sb}_{2} \mathrm{O}_{3}$ nanoparticles [18].

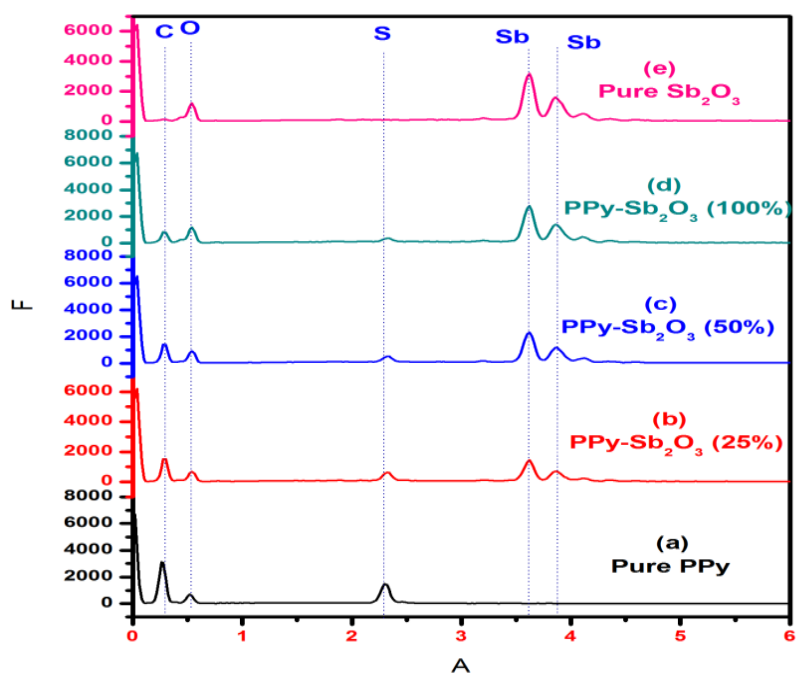

Fig.9 EDAX spectra of pure $\mathrm{PPy}(\mathrm{a}), \mathrm{PPy}_{-} \mathrm{Sb}_{2} \mathrm{O}_{3}$ nanocomposites (b,c,d) and pure $\mathrm{Sb}_{2} \mathrm{O}_{3} \mathrm{nPs}(\mathrm{e})$

\begin{tabular}{|c|c|c|c|c|c|}
\hline \multirow{2}{*}{$\begin{array}{c}\text { Sample } \\
\text { Name }\end{array}$} & \multicolumn{5}{|c|}{ Weight (\%) } \\
\hline & Carbon & Oxygen & Sulfur & Antimony & Total \\
\hline $\begin{array}{l}\text { Pure } \\
\text { PPy }\end{array}$ & 69.32 & 24.24 & 6.44 & - & 100 \\
\hline $\begin{array}{c}\mathrm{PPy}- \\
\mathrm{Sb}_{2} \mathrm{O}_{3} \\
(25 \%)\end{array}$ & 40.66 & 19.60 & 4.02 & 35.72 & 100 \\
\hline $\begin{array}{c}\text { PPy- } \\
\mathrm{Sb}_{2} \mathrm{O}_{3} \\
(50 \%)\end{array}$ & 30.02 & 17.35 & 2.65 & 49.98 & 100 \\
\hline $\begin{array}{c}\text { PPy- } \\
\mathrm{Sb}_{2} \mathrm{O}_{3} \\
(100 \%)\end{array}$ & 17.86 & 18.24 & 1.85 & 62.05 & 100 \\
\hline $\begin{array}{c}\text { Pure } \\
\mathrm{Sb}_{2} \mathrm{O}_{3}\end{array}$ & 14.80 & - & - & 85.20 & 100 \\
\hline
\end{tabular}

Table.5 Element analysis data of pure $\mathrm{PPy}, \mathrm{PPy}-\mathrm{Sb}_{2} \mathrm{O}_{3}$ nanocomposites and pure $\mathrm{Sb}_{2} \mathrm{O}_{3} \mathrm{nPs}$

The element contents of $\mathrm{PPy}_{-} \mathrm{Sb}_{2} \mathrm{O}_{3} \quad(25-100 \%)$ nanocomposites show a higher $\mathrm{Sb}$ contents due to the formation of a large amount of $\mathrm{Sb}_{2} \mathrm{O}_{3}$.

\section{Conclusion}

The FTIR analysis is carriedout for pure PPy, $\mathrm{Sb}_{2} \mathrm{O}_{3}$ $n P s$ and $\mathrm{PPy}_{-} \mathrm{Sb}_{2} \mathrm{O}_{3} \quad(25-100 \%)$ nanocomposites systematically. The characteristics bands were observed for the corresponding materials. From the results, one can conclude that, the wavenumber region is shifted to higher values after $\mathrm{Sb}$ ion absorption. The results indicate that the co- ordination bond formed between the long pair of electrons of the atom in the PPy chain with the orbit of $\mathrm{Sb}$ atom of $\mathrm{Sb}_{2} \mathrm{O}_{3}$, indicating the strength of $\mathrm{PPy}-\mathrm{Sb}_{2} \mathrm{O}_{3}$ nanocomposites have been synthesized successfully and the observed shift which indicates the interaction between $\mathrm{PPy}$ and $\mathrm{Sb}_{2} \mathrm{O}_{3}$ nPs. UVvisible spectra results indicates that the absorption bands which are correspond to the transition of $\pi-\pi^{*}$. From the tauc plot, one can conclude that the band gap energy is calculated for each case of materials. Among the materials, the band gap energy $(3.46 \mathrm{eV})$ is obtained for pure PPy. The band gap is decreased with increasing $\mathrm{Sb}_{2} \mathrm{O}_{3}$ concentration and this indicates the $\mathrm{PPy}-\mathrm{Sb}_{2} \mathrm{O}_{3}$ interactions are significantly increased by increasing the $\mathrm{Sb}_{2} \mathrm{O}_{3}$ concentration loading to reduce the energy level intervals. X-Ray diffraction studies suggest the crystallographic nature of the materialsand from the report, we analyze the XRD patterns of pure $\mathrm{PPy}, \mathrm{Sb}_{2} \mathrm{O}_{3}$ $n P s$ and $\mathrm{PPy}-\mathrm{Sb}_{2} \mathrm{O}_{3}$ nanocomposites is in a systematic manner. The amorphous peak of pure PPy was appeared in addition to sharp peak, but the other patterns indicates the crystalinity was greatly improved the with addition of $\mathrm{Sb}_{2} \mathrm{O}_{3}$ form the nanocomposites. From the crystallite size calculations, the average crystallite size of $\mathrm{PPy}-\mathrm{Sb}_{2} \mathrm{O}_{3}$ (25 wt \%), $\mathrm{PPy}-\mathrm{Sb}_{2} \mathrm{O}_{3}$ $(50 \mathrm{wt} \%)$ and $\mathrm{PPy}-\mathrm{Sb}_{2} \mathrm{O}_{3}(100 \mathrm{wt} \%)$ are $97 \mathrm{~nm}, 170 \mathrm{~nm}$ and $176 \mathrm{~nm}$ respectively. From this, one can inferred that the lowest average crystallite size is observed for $\mathrm{PPy}-\mathrm{Sb}_{2} \mathrm{O}_{3}$ $(25 \%)$. The strain and dislocation density calculation and the data suggest the crystallographic nature and defects of the materials. Thermogravimetric results of the pure $\mathrm{PPy}, \mathrm{Sb}_{2} \mathrm{O}_{3}$ nPs and $\mathrm{PPy}_{-} \mathrm{Sb}_{2} \mathrm{O}_{3}$ (25-100\%) nanocomposites suggest that thermal behavior and stability of the materials and the number of stages of decomposition may vary depending upon the materials. In this report, the lowest number of stages (2) is observed for pure PPy. The residual mass of $\mathrm{PPy}-\mathrm{Sb}_{2} \mathrm{O}_{3}(25-$ $100 \mathrm{wt} \%$ ) is increased, when the composition increase from $\mathrm{PPy}-\mathrm{Sb}_{2} \mathrm{O}_{3}$ (25 wt\%) to $\mathrm{PPy}-\mathrm{Sb}_{2} \mathrm{O}_{3} \quad(100 \mathrm{wt} \%)$. This is because, the increase of loading amount of $\mathrm{Sb}_{2} \mathrm{O}_{3}$ in the matrix of PPy, but the residual temperature is almost constant for all the cases. From the differential scanning calorimetric analysis, one can reveal the stages in which the molecules of various categories eliminating from the surface. The exothermic and endothermic peaks suggests that the polymer decomposition is found in the case of $\mathrm{PPy}-\mathrm{Sb}_{2} \mathrm{O}_{3}$ nanocomposites. These kinds of analysis help us to estimate the thermal stability of pure $\mathrm{PPy}, \mathrm{Sb}_{2} \mathrm{O}_{3}$ nPs and $\mathrm{PPy}-\mathrm{Sb}_{2} \mathrm{O}_{3}(25-100 \%)$ nanocomposites. In this report, the surface morphological analyses of pure PPy, $\mathrm{Sb}_{2} \mathrm{O}_{3}$ nPs and $\mathrm{PPy}-\mathrm{Sb}_{2} \mathrm{O}_{3}$ (25-100\%) nanocomposites are carriedout successfully. Actually, the particles are not in spherical in size for the all the cases. Instead, the particles are agglomerated initially and the some square shaped particles are also found and also there are some surface modifications, due to the agglomeration of the particles, so that the core shell like structure is formed on the surface of PPy matrix and this can be seen clearly from the morphological data. From the EDAX analysis, the elemental composition of pure PPy, $\mathrm{Sb}_{2} \mathrm{O}_{3}$ nPs and $\mathrm{PPy}-\mathrm{Sb}_{2} \mathrm{O}_{3}(25-100 \mathrm{wt} \%)$ is estimated clearly. From the increasing trend of antimony, one can inferred the loading amount of $\mathrm{Sb}_{2} \mathrm{O}_{3}$ in the matrix of PPy. This kind of analysis helps us to gain more information about the structure and behavior of the materials. 


\section{REFERENCES}

[1] Li Cui, Juan Li, Xiao-gang Zhang. Materials Letters 63 683-686.

[2] Pi-Guey Su, Lin-Nan Huang. Sensors and Actuators B 123 (2007) 501-507.

[3] Yu Xiea, Xiaowei Hong, Yunhua Gao, Mingjun Li, Jinmei Liu, Juan Wang, Jing Lu. Synthetic Metals 162 (2012) 677-681.

[4] Komilla Suri, S. Annapoorni, R.P. Tandon, N.C. Mehra. Synthetic Metals 126 (2002) 137-142.

[5] Komilla Sari, S.Annapoorni, A.K.Sarkar, R.P.Tandon. Sensors and Actuators B 81 (2002) 277-282.

[6] Ze Hua Dong, Yan Li Wei, Wei Shi, Guo An Zhang. Materials Chemistry and Physics 131 (2011) 529-534.

[7] Madhumita Bhaumik, Arjun Maity, V.V. Srinivasu, Maurice S. Onyango. Journal of Hazardous Materials $190 \quad$ (2011) 381-390.

[8] Sukanta De, Ashis Dey, S.K. De. Solid State Communications 137 (2006) 662-667.

[9] Kousik Dutta, S.K. De. Solid State Communications". 140 (2006) 167-171.

[10] Debabrata Nandi, Arup Kumar Ghosh, Kaushik Gupta, Amitabha De, Pintu Sen, Ankan Duttachowdhury, Uday Chand Ghosh. Materials Research Bulletin 47 (2012) 2095-2103.

[11] Wenqin Wang, Wenli Li, Ruifeng Zhang, Jianjun Wang. Synthetic Metals 160 (2010) 2255-2259.

[12] Haldorai Yuvaraj, Eun Ju Park, Yeong-Soon Gal, Kwon Taek Lim. Colloids and Surfaces A: Physicochem. Eng. Aspects 313-314 (2008) 300-303.

[13] Manawwer Alam, Anees A. Ansari, Mohammed Rafi Shaik, Naser M. Alandis. Arabian Journal of Chemistry

[14] Emine Temizel, Esra Ayan, Mehmet S, enel, Hamit Mustafa S. Yavuz, Huseyin Kavas, Abdulhadi Baykal, Ramazan Ozturk. Materials Chemistry and Physics 131 (2011) 284-291.

[15] Hamid Heydarzadeh Darzi, Saeedeh Gilani Larimi, Ghasem Najafpour Darzi. Synthetic Metals (2011).

[16] S.Y. Chew, Z.P. Guo, J.Z. Wang, J. Chen, P. Munroe, S.H. $\mathrm{Ng}$, L. Zhao, H.K. Liu. Electrochemistry Communications 9 (2007) 941-946.

[17] C. Lai, G.R. Li, Y.Y. Dou, X.P. Gao. Electrochimica Acta 55 (2010) 4567-4572.

[18] Madhumita Bhaumika, Taile Yvonne Leswifia, Arjun Maity, V.V. Srinivasu, Maurice S. Onyango. Journal of Hazardous Materials 186 (2011) 150-159. 